\title{
Education Marketing Research
}

\author{
Xiaogang Yang \\ Chengdu Normal University, Chengdu, China \\ Email:930761897@qq.com
}

How to cite this paper: Yang, X.G. (2016) Education Marketing Research. Theoretical Economics Letters, 6, 1180-1185. http://dx.doi.org/10.4236/tel.2016.65111

Received: September 28, 2016

Accepted: October 19, 2016

Published: October 21, 2016

Copyright $(\odot 2016$ by author and Scientific Research Publishing Inc. This work is licensed under the Creative Commons Attribution International License (CC BY 4.0).

http://creativecommons.org/licenses/by/4.0/ (c) (i) Open Access

\begin{abstract}
"Education marketing" is a new concept used in high frequency interiorly in recent years, but it has significantly different interpretations in the educational circles and business circles, extremely easy to cause the misuse and mix, which is not conducive to the development and application of this new subject of marketing. The analysis of this paper shows that: there are four essential differences in the understanding of "educational marketing" in the education and business circles and two suggestions are put forward to solve the problem.
\end{abstract}

\section{Keywords}

Education Marketing, Educational Organization Marketing, Consumer Education, Educational Marketing

\section{Background}

Marketing science is the most active discipline with new ideas, new technologies emerging in endlessly, involved in the broader field, the so-called "no place no marketing, no time no marketing". With the increasingly rich marketing practices at the same time, there have been some confusions of the concept of the situation needed to be cleaned up. "Education marketing" is the use of more professional terminology in recent years, furthermore, its theoretical research and practice is brilliant. According to the exploration of the analysis, the author found that the educational circles and business circles have obvious ambiguity of the concept of "education marketing" and present some confusion in understanding its scientificalness, accuracy and applicability. This paper is on the concept of "education marketing" so that to reform from the bottom and put forward suggestions to solve the ambiguity, so that to achieve the scientific development of education marketing. 


\section{Two Interpretations of Educational Marketing}

\subsection{Education Field}

In the field of education, "education marketing" originated in the United States' higher education. From twentieth Century 50 to 60s, the United States University experienced rapid developments and massive expansion. In 70s, the economic recessed, so the government funding and social forces reduced, and the number of school-age population declined, so that the competition was increasingly fierce. In order to overcome the crisis of existence and drew lessons from the theory and practice of marketing, the marketing of higher education received extensive attention. Kotler in his "Introduction to marketing" mentioned: "In the past, marketing has been widely used in the industrial and commercial sector. But in recent years, marketing has become a part of the development strategy of many non-profit organizations such as universities, museums, hospitals and other institutions" [1]. In 80s, with the rapid popularization of information network and the wave of international education, American higher education is full of opportunities and challenges in the new era, and the higher education marketing is gradually mature. In September 1989, the first year of marketing for higher education will be held in San Francisco, then once a year, extensive research on strategy and marketing of international higher education, higher education marketing, education input and output, consumer behavior, enrollment and employment of college graduates, and gradually develops into an international conference. In the meantime, due to the European and American countries' promotion of market-oriented reform of education, the introduction of free competition mechanism in primary and secondary education, education and marketing have begun to enter the primary education. Practice shows that the research and implementation of education marketing promote the higher education management philosophy and business model, enhance the relationship between University and society, improve the higher education service and education product construction, at the same time, help American universities attract more donations and investments, reduce the cost of education, increase the income of colleges and universities. However, in general, educational marketing is a new subject, and it is still in the research stage of "paradigm". Does Education marketing conflict with education ethics? How to establish the basic theory framework of educational marketing? How to implement relationship marketing, school internal marketing and quality management? How to correct the school marketing is not moral image and play the brand effect of the quality of education? And so on, a lot of problems have yet to be discussed [2].

Since twenty-first Century, with the rapid development of the socialist market economy, China's higher education stepped into the popularization with the expansion of college enrollment and the new universities continue to emerge. Because of the shortage of education funds, the nation reforms the way of investment of education in the operation and the cost compensation mechanism, so that the pressure increases, furthermore, foreign universities have entered one after another, and the competition grows increasingly fierce. The original school system is facing serious challenges. In 
order to deal with these changes, private colleges and universities as the first, all kinds of higher education institutions began to introduce educational marketing.

The domestic educational circles of "education marketing" interpretation, the most representative is that: education marketing is the educational services offered by educational institutions at all levels who adopt creation to meet the social and personal needs, the market management process in order to achieve the purpose of education, maintain the survival and development of educational institutions [3]. Later, some scholars pointed out: education marketing is a market management process planned by the educational institutions in long-term to achieve the goals of education better, improve the efficiency of modern university education, provide high quality services to meet the individual needs and social developments according to consumes' demand, achieve their own developments and the country's education policy [4].

Education marketing brings some positive effects to the reform of the education system, education oriented education and the economic and social needs, expansion of school autonomy, decrease of the running cost, enhancement of operating efficiency, but also faces some controversy, such as the education industry, the problem of education fairness, education as a non-profit industry whether suitable for marketing or not etc.

\subsection{Business Field}

In the business world, from the beginning of 1990s, "education marketing" also began to rise, but its definition of "education marketing" and the education sector was quite different. In the field of education itself, education of "marketing" has a lot of controversies, while timidly, business circles on the education marketing have put up a pageantry, like a raging fire. I used "Baidu" to search "education marketing", the only interpretation defined namely was: education marketing is the marketing concept and marketing mode that introduce the new consumption concept, new life style through conference marketing (including lectures, seminars, meetings, visits, new technology exhibition, demonstration, product launches), interpersonal communication marketing, knowledge marketing, experiential marketing, cultural marketing, sports marketing and other forms of marketing to educate and guide consumers and potential consumers, so that consumers and potential consumers can accept the new concept of consumption and lifestyles, and change the original thinking habits, consumption habits and lifestyles, then make consumer lifestyles and the marketing level upgrade. At the same time, some scholars defined education marketing as: education marketing is the process under the guidance of marketing theory that propagates, educates and guides relevant knowledge to target consumers systematically, which also sets service as a platform to meet customer demand for the product or service, and realize enterprise value interaction [5]. "Educational marketing" activities in the domestic enterprises began to enter the successful operation of the Chinese market, Colgate, Amway, after which the rapid promotion, and formed a variety of educational marketing model". 


\section{Different Connotations of Two Kinds of Educational Marketing Concept}

Education and business circles use the "educational marketing" at the same time, but their interpretations are self -built systems. From the names, though they are both the compound words of "collage education" and "marketing", the "education" is not completely equal to that of "education", so as the "marketing". In the author's opinion, there are obvious differences between the subject and object, environment and reason, the goal and the quality, scope and content these essential characteristics of "educational marketing" in the education and business circles.

\subsection{The Differences of Marketing Subject and Object}

In the education sector, the executors of education marketing are all types of educational institutions at all levels, according to it, Kotler Philip named his own work related "strategic marketing of education institutions" [6]. At present, scholars generally believe that high school, occupation technical colleges and private colleges and training organizations and other social conditions can become the subject of marketing conditionally, apart from the compulsory education in primary and secondary schools and special schools. The reason of "conditional" and "exclusion" is that marketing is "profit-making", and education is a non-profit public welfare undertaking. In fact, as a theory or technology, marketing science can improve management mechanism effectively, reduce cost and improve benefit (including social benefits), which has already been borrowed for various non-profit institutions: "the government marketing", "social marketing", "city marketing" have been implemented and became the normalcy. Under the premise of non-profit, all kinds of educational institutions at various levels can also become the main bodies of marketing. Education marketing is the object of education services.

In the business world, the subject of educational marketing is the business enterprises. The enterprise is the market's main body in order to make profit. "Education" here is the means of marketing but not the main body. The enterprise adopts the dissemination of knowledge continuously, and uses the new consumption concept and new lifestyles related to its products to educate and guide customers, ultimately makes customers accept the product, realize the value of the exchange, then reach a basic goal of profit. The object of enterprise education marketing is the various entities and intangible products provided by enterprises.

\subsection{Differences of Environmental Conditions and Motivations}

Educational circles' marketing originated in the United States in 1970s, when the environment faced by higher education was undergoing profound changes: economic recession, relative reduction of funds, the decrease of the school-age enrollment and competition in education market from a seller's market to a buyer's market, so that institutions of Higher Education were forced out of the ivory tower and referred the theory and operation of marketing to attract students, and improved school funding. 
Recent years in our country, with the development of market economy, state reformed investment mechanism of higher education, and the consumers of education (including students, families and employers) became more and more mature and rational, demanding of return increasing, competition fiercer. No other than the driving of these background changes, some private colleges and universities take the lead in the application of educational marketing, and thus promote its continuous development.

In the business world, the production of educational marketing originates from the 1990s "consumer education" activities. The past marketing is based on the assumption that the economic rational person thinks that the consumer is the rational market main body. But because the great modern products are abundant, transactions are becoming more and more complicated, and the information share and utilization are very asymmetric, which often make consumers confused than fit in, and actually become vulnerable groups who are not mature enough and finitely rational. Therefore, to protect the interests of consumers, government organizations carried out educational activities to enhance the consumer concept (including personal values, social values and life style of modern civilization view), the quality of consumers (including commodity knowledge, ability to buy). Industrial and commercial enterprises actively adapt to this environment, timely implementing and developing their own educational marketing. In fact, education marketing meets the customer's desire for commodity knowledge, closes the distance between enterprises and consumers, and makes good effects to stimulating the potential demand, cultivating the market, developing the market, promoting sales.

\subsection{The Difference of Marketing Objectives and Nature}

In our country, the non-profit organization nature of education institutions determines that the marketing goal is not simply the pursuit of economic interests, but improvement of the management mechanism, decrease of the cost, improvement of the performance, better satisfaction of students, parents and employers, enhancement to the school's social benefits. It is clear that the nature of educational marketing is non-profit marketing, just like government marketing and social marketing. And the educational marketing of the business enterprise is the same as other marketing tools.

\subsection{Different of the Scope and Content of Marketing}

In the field of education, the scope and content of education marketing should involve the marketing theory and method of overall education, including market survey and forecast, market strategy (market segmentation, target market and market positioning), marketing strategy (product, price, channel, promotion and marketing management). The education marketing is a kind of integration method, which belongs to the scope of the promotion strategy. The business community's "education" is actually an activity that the community chooses the knowledge conducive to the promotion of product sales or establishing a corporate image of, so that to educate and induce target customers, let consumers buy "rational expectations", in order to achieve the purpose of promotion. From the point of view of marketing technology, this educational marketing is 
a means of information communication in the final analysis, often as the main mode of information dissemination.

\section{Conclusions}

As mentioned above, the concept of "educational marketing" is used both in education and business world, but it is not scientific and conducive to the development of marketing science. In order to solve this contradiction, the author puts forward the following suggestions:

In the field of education, we still use the concept of "education marketing", because it returns to the original meaning of "application of marketing management's theories and methods in education field". Here, the "education" can be thought as a field, or an industry, as the "automobile marketing" and "sports marketing"; and in the business sector, we use "knowledge marketing", "marketing training" and "marketing department" concepts, which contain the meaning of "education", and returns to the use of means.

\section{References}

[1] Kotler, P. (2000) Marketing Management. Huaxia Publishing House, Beijing.

[2] Meng, X.L. (2015) Marketing of Higher Education Schools: Problems and Strategies in China from the Practice of the United States. Journal of Nanjing University of Radio and Television, No. 3, 38.

[3] Kong, F.S (2011) A Brief Discussion on the Marketing Strategy of Higher Education. China Science and Technology, No. 17, 78.

[4] Feng, X.F. (2007) Analysis of the Marketing of Higher Education. Journal of Inner Mongolia Agricultural University (Social Science Edition), No. 1, 187.

[5] Lin, J.K. (2004) Marketing Innovation and Marketing of Education. Dongyue Journal, No. $5,190$.

[6] Kotler, P. (2005) Strategic Marketing for Educational Institutions. Enterprise Management Publishing House, Beijing.

Submit or recommend next manuscript to SCIRP and we will provide best service for you:

Accepting pre-submission inquiries through Email, Facebook, LinkedIn, Twitter, etc. A wide selection of journals (inclusive of 9 subjects, more than 200 journals)

Providing 24-hour high-quality service

User-friendly online submission system

Fair and swift peer-review system

Efficient typesetting and proofreading procedure

Display of the result of downloads and visits, as well as the number of cited articles

Maximum dissemination of your research work

Submit your manuscript at: http://papersubmission.scirp.org/

Or contact tel@scirp.org 